Article

\title{
Pinpointed Stimulation of EphA2 Receptors via DNA-Templated Oligovalence
}

\author{
Christin Möser ${ }^{1,2}$, Jessica S. Lorenz ${ }^{1,3}$, Martin Sajfutdinow ${ }^{1,4}$ and David M. Smith 1,3,* \\ 1 DNA Nanodevices Unit, Department Diagnostics, Fraunhofer Institute for Cell Therapy and Immunology \\ IZI, 04103 Leipzig, Germany; christin.moeser@izi.fraunhofer.de (C.M.); \\ jessica.lorenz@izi.fraunhofer.de (J.S.L.); martin.sajfutdinow@izi.fraunhofer.de (M.S.) \\ 2 Institute of Biochemistry and Biology, Faculty of Science, University of Potsdam, 14476 Potsdam, Germany \\ 3 Peter Debye Institute for Soft Matter Physics, Faculty of Physics and Earth Sciences, University of Leipzig, \\ 04103 Leipzig, Germany \\ 4 Fraunhofer Project Center “Microelectronic and Optical Systems for Biomedicine” (MEOS), \\ 99099 Erfurt, Germany \\ * Correspondence: david.smith@izi.fraunhofer.de; Tel.: +49-341-35536-9311
}

Received: 29 October 2018; Accepted: 2 November 2018; Published: 6 November 2018

check for updates

\begin{abstract}
DNA nanostructures enable the attachment of functional molecules to nearly any unique location on their underlying structure. Due to their single-base-pair structural resolution, several ligands can be spatially arranged and closely controlled according to the geometry of their desired target, resulting in optimized binding and/or signaling interactions. Here, the efficacy of SWL, an ephrin-mimicking peptide that binds specifically to EphrinA2 (EphA2) receptors, increased by presenting up to three of these peptides on small DNA nanostructures in an oligovalent manner. Ephrin signaling pathways play crucial roles in tumor development and progression. Moreover, Eph receptors are potential targets in cancer diagnosis and treatment. Here, the quantitative impact of SWL valency on binding, phosphorylation (key player for activation) and phenotype regulation in EphA2-expressing prostate cancer cells was demonstrated. EphA2 phosphorylation was significantly increased by DNA trimers carrying three SWL peptides compared to monovalent SWL. In comparison to one of EphA2's natural ligands ephrin-A1, which is known to bind promiscuously to multiple receptors, pinpointed targeting of EphA2 by oligovalent DNA-SWL constructs showed enhanced cell retraction. Overall, we show that DNA scaffolds can increase the potency of weak signaling peptides through oligovalent presentation and serve as potential tools for examination of complex signaling pathways.
\end{abstract}

Keywords: DNA nanostructure; ephrin; EphA2; SWL; PC-3 cells; multivalence

\section{Introduction}

The field of structural DNA nanotechnology is based on using DNA as construction material for building nanometer-scale objects [1-6]. Stability, specific base pairing and the biocompatibility of DNA molecules are beneficial properties that have strengthened the idea of building discrete nanostructures according to the diverse methods of DNA self-assembly and using them for a variety of applications. To equip DNA-based objects with well-defined roles, it is possible to attach functional molecules (e.g., fluorophores, peptides and aptamers) internally or on the ends of the constituent DNA strands via different chemical reactions [7]. Since the underlying nucleotide sequence, and thereby the exact molecular structure of these DNA-based objects can be determined during the design process, they can be used as scaffolds to create precise geometric arrangements of conjugated molecules with single-nanometer resolution. In the case of double-stranded DNA, a single base pair corresponds to 
a $0.34 \mathrm{~nm}$ rise along the helical axis, facilitating a more precise spatial resolution for the placement of single molecules than is practically available through other means of top-down lithography or bottom-up molecular programming. This is particularly relevant for interacting with and even controlling the behaviors of biological systems, since, by attaching several ligands to DNA objects, one can achieve optimized binding and activation of target structures such as proteins and receptors by matching their naturally defined distances between different binding or active sites. Consequently, DNA nanostructures have been studied as platforms for therapeutic agents, particularly anti-cancer compounds [8-14].

Erythropoietin-producing hepatocellular carcinoma (Eph) receptors are receptor tyrosine kinases (RTKs) that are activated by Eph family receptor interacting protein (ephrin) ligands. The Eph family receptors can be divided into two subclasses: EphA and EphB whereas the first is mainly bound by ephrin-A ligands and the second by ephrin-B ligands $[15,16]$. Since both receptor and ligand are located on the extracellular side of the cell membrane, the contact of two adjacent cells is necessary for interaction and activation [17]. A special feature of Eph-ephrin signaling is bidirectional signal transduction in both Eph- ("forward" signaling) and ephrin-presenting cells ("reserve" signaling). Ephrin pathways are important for angiogenesis, adult tissue homeostasis, embryogenesis, and other developmental processes. However, they are additionally key players in many pathological conditions; for example, the EphA2 receptor is widely upregulated in many cancer types (breast [18], prostate [19], ovarian [20], lung [21]). EphA2 overexpression is linked to poor clinical outcome and malignant progression, but those properties are most likely independent of the ligand binding to the receptor, and instead result from crosstalk between EphA2 and Akt [22,23]. Interestingly, Eph receptors can also act as tumor suppressors when activated by ephrin or ephrin-like ligands. Downstream signaling correlates with inhibition of cell proliferation, migration, invasiveness and adhesion, which are regulated via RAS-ERK [24], Akt-mTORC1 [25] and several integrin-dependent pathways [26]. As a result, Eph receptors and ephrins are increasingly studied as potential therapeutic targets $[27,28]$. In addition, these receptors are internalized upon ligand binding and their expression in normal tissues is low compared to cancerous tissue, making them suitable to specifically deliver anti-cancer agents $[29,30]$ or serve as specific tissue markers for imaging agents [31,32].

The agonistic ephrin-mimicking peptide SWL was previously discovered by phage display and was shown to specifically bind EphA2 receptors on their ligand-binding domain, thereby activating downstream signaling pathways [33,34]. By presenting two covalently conjugated SWL peptides as dimer, the binding to EphA2 receptors could be enhanced more than 10-fold [35]. However, this was accompanied with the disadvantage of a decreased half-life compared to the SWL monomer, hindering thorough assessment of cooperative binding in cellular systems. In contrast to the natural ephrin ligands, which are considered to be promiscuous due to their propensity to bind and stimulate multiple Eph receptors [36], SWL's complete specificity to EphA2 eliminates the possibility of downstream interference reported to occur as a result of simultaneously triggering competing pathways $[37,38]$.

Here, we adopt a DNA-templated approach, where we bind up to three SWL peptide monomers to stable DNA nanostructures and examine the influence of this oligovalent presentation on PC-3 prostate cancer cells that overexpress the EphA2 receptor. The principle of oligovalent presentation and binding is ubiquitously found in nature, being, among others, the basis of specific cell-cell interactions and pathogen-host recognition [39]. It is based on several simultaneously occurring interactions that collectively are stronger than one single interaction would be. Upon binding of the dimeric ephrin ligand to a pair of Eph receptors, their dimerization is followed by autophosphorylation of tyrosine residues in the cytosolic domain of the receptors and subsequent activation of signaling pathways. In contrast to most RTKs, downstream Eph-ephrin signaling requires the formation of higher-order clusters [40]. Since the association of as few as three ligand-receptor complexes has been shown to cause oligomerization [41,42] a three-valent DNA template called the "DNA trimer" was chosen for this study (Figure 1). It consists of three partially complementary strands, has a molecular mass of approximately $28 \mathrm{kDa}$ when unmodified, and of approximately $34 \mathrm{kDa}$ when modified with three 
monomeric SWL peptides. A related DNA-based approach to activate EphA2 signaling pathways by controlling cluster proximity was introduced by Shaw et al. in 2014 [8]. They engineered a large DNA origami structure (approximately $5 \mathrm{MDa}$ in size) that positions pairs of dimeric ephrin-A5 protein ligands at two different distances from each other, 43 and $100 \mathrm{~nm}$. Here, we chose the comparatively small SWL peptide $(1.7 \mathrm{kDa})$ instead of natural ephrin protein ligands (e.g., ephrin-A1 with molecular weight (MW) approx. $21 \mathrm{kDa}$ ) since these mimic the binding and stimulation activity of the full ligand, albeit with specificity to EphA2, while still allowing the exploitation of sub-nanometer spatial resolution that DNA can provide [43]. When conjugated at the ends of the arms on the DNA trimer, SWL peptides are approximately $9 \mathrm{~nm}$ apart when the structure is in outstretched conformation. Although the structure's arms are rigid on these length scales (DNA persistence length is $50 \mathrm{~nm}$ ), the junction in the middle supplies the DNA trimers with needed flexibility for adjusting to the exact conformation of the EphA2 ligand-binding domain. Furthermore, nanostructures built from DNA or other modified nucleotide variants are very stable molecules [44] and therefore can be more suitable to survive in a biological environment than peptides alone [35] (Figure A4). To place three SWL peptides onto the DNA trimer, $\mathrm{N}$-hydroxysuccinimide (NHS) ester reactions as well as copper-free click chemistry reactions [45-49] were performed (Figure 1b) to attain nearly quantitative yields.
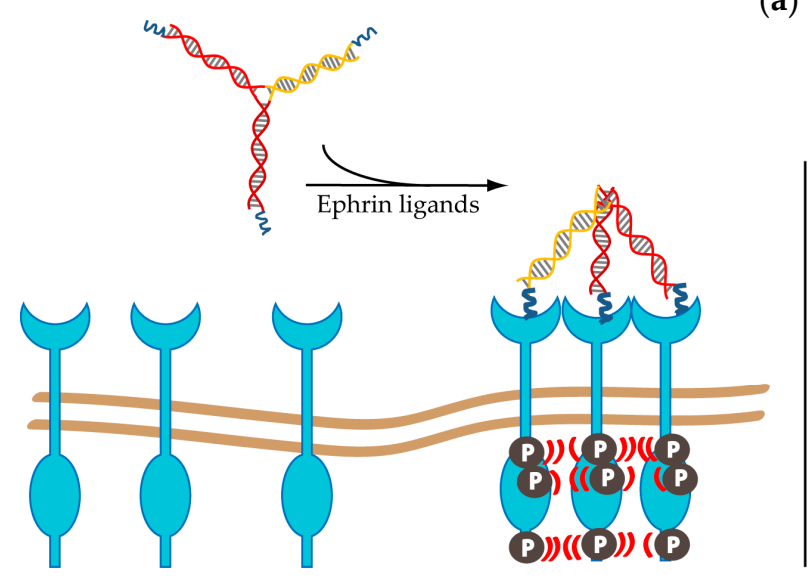

inactive EphA2

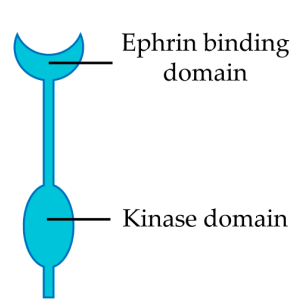

active EphA2 receptor

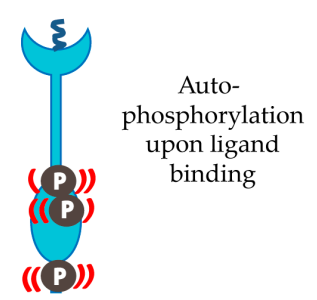

(b)

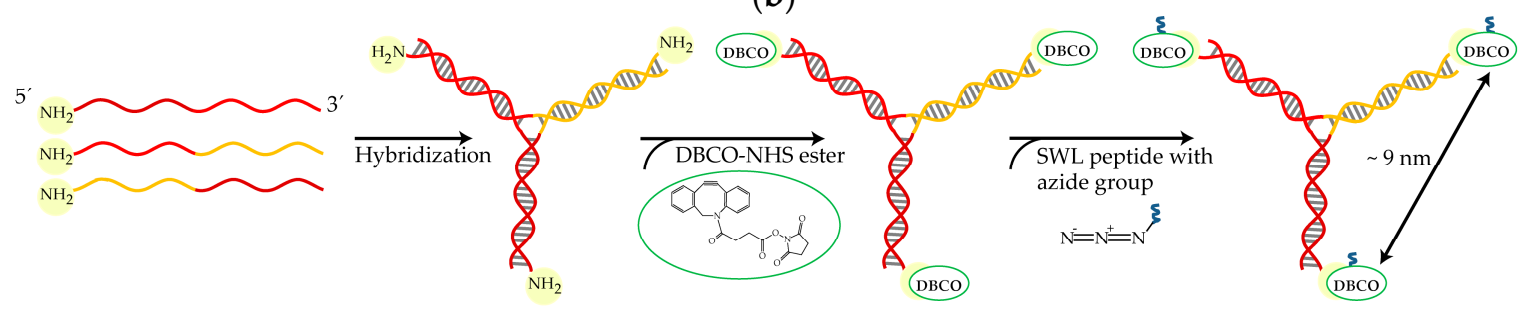

Figure 1. SWL-coupled DNA trimer and its action on EphA2 receptors: (a) EphA2 (light blue) cluster formation and subsequent autophosphorylation due to the presence of three peptides SWL attached to DNA trimers. Inactive Eph receptors are loosely distributed on cell membranes and become ordered when activated [50]. (b) Synthesis of SWL-coupled DNA trimer. Three partially complementary strands (complementary parts indicated by same color) are hybridized to form the DNA structure. Primary amine groups on $5^{\prime}$ ends react with dibenzylcyclooctyne (DBCO)-NHS esters (green) and form amid bonds. Peptides SWL with azide group on the C-terminus (dark blue) react with DBCO to form stable triazoles.

The specific binding of SWL-coupled DNA trimers to PC-3 prostate cancer cells known to overexpress EphA2 was evaluated via ligand titration in in flow cytometry experiments. Subsequently, their ability to activate these receptors via phosphorylation was evaluated for relative efficacy and potency. As a result of activation, cells undergo characteristic morphological changes, where they 
"round up" and retract their periphery. We further characterized the assembly and purity of SWL-DNA trimers, investigated their stability in serum-containing medium and when incubated together with cells.

\section{Results}

\subsection{Binding of SWL-DNA Trimers to PC-3 Cells}

PC-3 cells are known to overexpress EphA2 receptors [19] and to confirm this, we initially probed its expression using a phycoerythrin (PE) labeled anti-human EphA2 antibody in flow cytometry experiments. As a negative control HL-60 cells, which should only express these receptors after maturation [51], were tested and the expected lack of expression was confirmed compared to PC-3 cells (Figure A5). EphA2 expressing PC-3 cells were then treated with different concentrations of DNA trimers carrying both a Cy3 dye and between 0-3 SWL peptides and were subsequently analyzed via flow cytometry (Figure 2). As expected, binding curves revealed that the construct with three SWL peptides (3xSWL-DNA) displays highest binding activity. In comparison, the binding activity of structures carrying one SWL peptide is nearly indistinguishable from nonspecific interactions occurring between the bare DNA trimer and cells. Structures carrying two peptides do display moderate binding, although at approximately one-quarter of the levels of the three-peptide structures at the highest concentration.

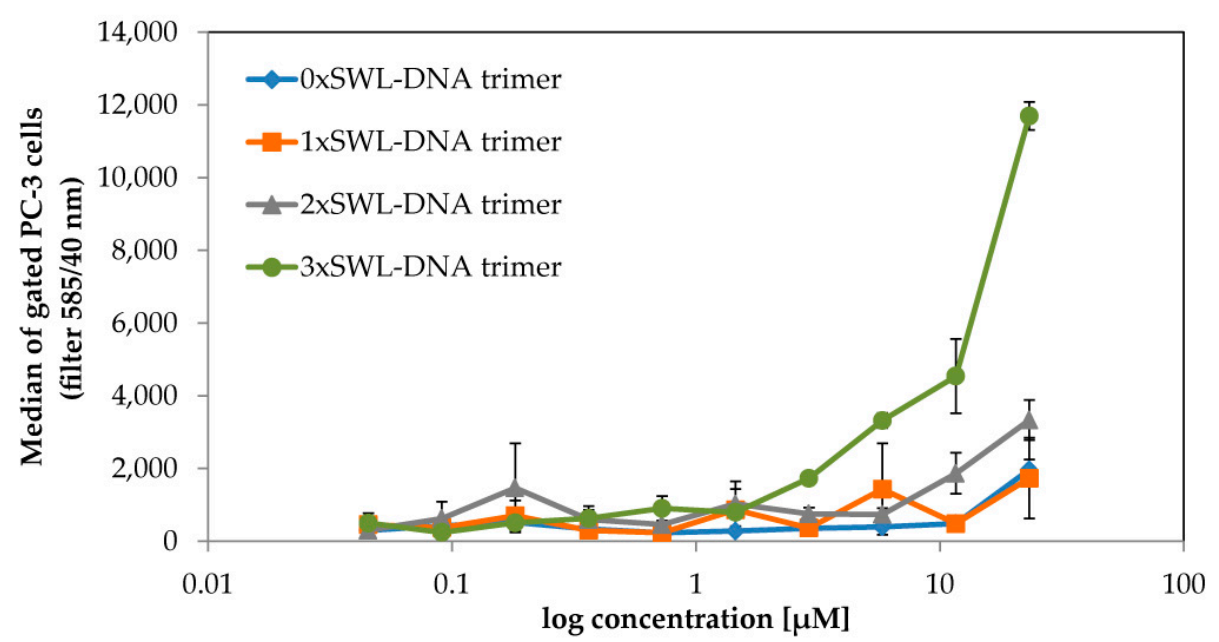

Figure 2. Binding of SWL-coupled DNA trimers to EphA2-expressing PC-3 cells. Serum-starved PC-3 cells were treated with SWL-DNA trimer constructs (labeled with Cy3, carrying 0-3 peptides SWL) in duplicates for $30 \mathrm{~min}$ at room temperature. Cells were gated and normalized by cell number. Displayed on the y-axis are average values of emission which were observed using a 585/40 nm filter (FL2-A) with standard deviation presented as error bars. The $\mathrm{x}$-axis indicates concentrations of the constructs in terms of DNA. Scatter plots of raw data can be found in Figure A6.

For both the two- and three-peptide variants, the highest concentration of $25 \mu \mathrm{M}$ was not sufficient to reach saturation of binding, as was particularly evident in the latter case. This lack of saturation likely results from the active internalization via endocytosis following activation of EphA2 pathways, leading to an accumulation of fluorescent molecules within the cell interior. Nevertheless, the onset of binding above $1.5 \mu \mathrm{M}$ for the 3xSWL-DNA trimer is clear, compared to the 1xSWL-DNA and 2xSWL-DNA trimers, both of which do not show any comparable amount of binding below the maximum concentration. Due to the functional connection between receptor binding and internalization, biochemical signaling events and phenotype changes resulting from treatment with the DNA-peptide constructs were also examined. 


\subsection{Confirmation of EphA2 Pathway Activation via Receptor Phophorlyation}

The efficacy and potency $\left(\mathrm{EC}_{50}\right)$ of EphA2 receptor phosphorylation resulting from binding of the various constructs (monomeric peptide, mono-, bi- and trivalent presentation on the DNA trimer and positive/negative controls) was quantified by sandwich enzyme-linked immunosorbent assay (ELISA) detecting first EphA2 receptors and second phospho-tyrosines. To qualitatively compare the different ligands examined, a single concentration of the different ligands was analyzed first (Figure 3). These were chosen to be either near the onset of binding for the 3xSWL-DNA trimer for the DNA structures, or according to published protocols for the natural ligand and SWL. As a result of treatment, high phosphorylation signals were observed for the natural ligand ephrin-A1 $(1.5 \mu \mathrm{g} / \mathrm{mL})$ and the 3xSWL-DNA trimer ( $9 \mu \mathrm{M}$ of the trivalent construct). Monomeric SWL peptide $(150 \mu \mathrm{M})$ and 2xSWL-DNA trimer (9 $\mu \mathrm{M}$ of the bivalent construct) were of a comparable signal level to each other, clearly lower than the trivalent construct. However, it should be noted that the monovalent SWL peptide was applied at approximately a 16-fold higher concentration than the bivalent 2xSWL-DNA construct, clearly indicating a synergistic oligovalent effect rather than simply an additive effect due to doubling the total amount of SWL peptides in solution. As expected, negative controls of phosphate-buffered saline (PBS) or DNA trimers without any SWL peptides did not lead to any clearly enhanced phosphorylation of tyrosine residues.

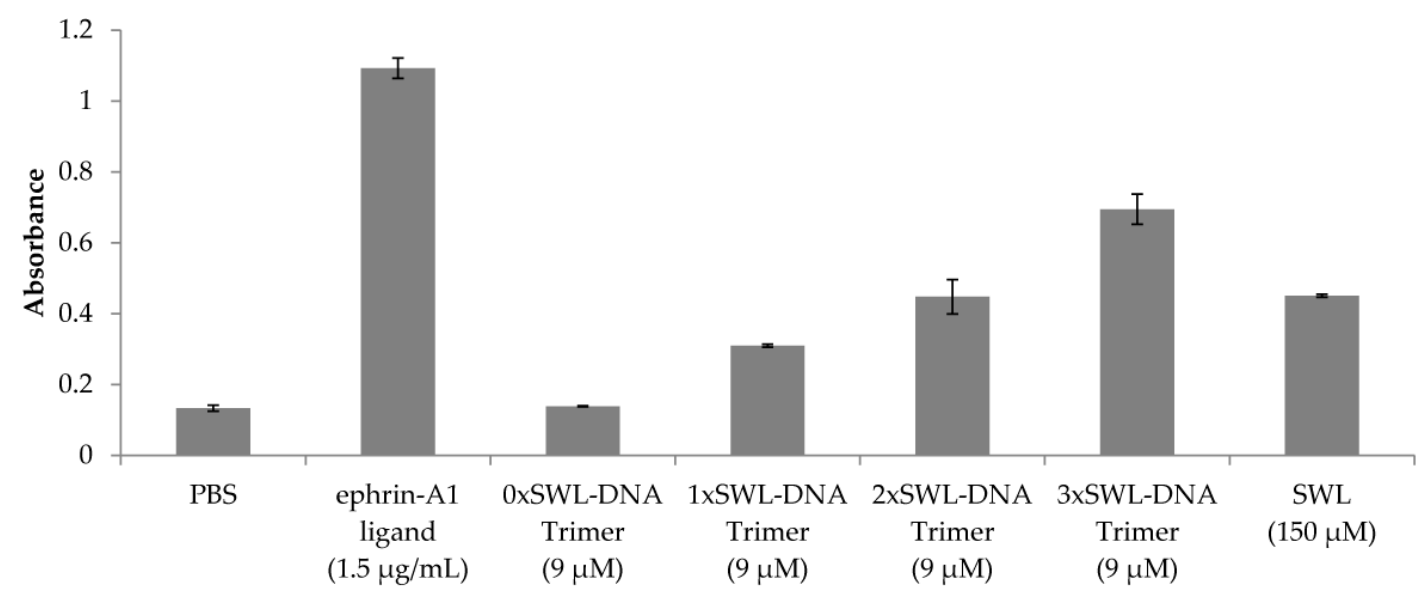

Figure 3. Qualitative analysis of EphA2 receptor phosphorylation. Serum-starved PC-3 cells were treated with different SWL-DNA trimer constructs $(9 \mu \mathrm{M})$, monomeric SWL peptide $(150 \mu \mathrm{M})$ and the natural ligand ephrin-A1 $(1.5 \mu \mathrm{g} / \mathrm{mL})$ in duplicates for $30 \mathrm{~min}$ at $37^{\circ} \mathrm{C}$. Cells were washed with $1 \times$ PBS twice and further treated according to the manufacturer's instructions. Displayed values are averages of net absorbance (difference between absorbance at $520 \mathrm{~nm}$ versus $450 \mathrm{~nm}$ ) with standard deviation presented as error bars.

Furthermore, the phosphorylation of EphA2 receptors resulting from the application of different concentrations of the ligands enabled the calculation of approximate $\mathrm{EC}_{50}$ values for the DNA-peptide constructs by least-square analysis (Figure 4, Equation (1)) [52]. As expected, 3xSWL-DNA trimers led to the highest phosphorylation signal $\left(\mathrm{EC}_{50}=0.0190 \pm 0.0046 \mu \mathrm{M}\right)$, i.e., overall efficacy, followed by $2 x S W L-D N A$ trimers $\left(\mathrm{EC}_{50}=0.0572 \pm 0.0113 \mu \mathrm{M}\right)$ and 1xSWL-DNA trimers $\left(\mathrm{EC}_{50}=2.7427 \pm 1.9837 \mu \mathrm{M}\right)$ for concentrations up to $30 \mu \mathrm{M}$. For $\mathrm{SWL}$, concentrations up to $500 \mu \mathrm{M}$ were tested and fitting revealed an $\mathrm{EC}_{50}$ value of $153.8287 \pm 115.3869 \mu \mathrm{M}$. DNA trimers without any SWL (0xSWL-DNA trimer) did not evoke phosphorylation of EphA2 receptors, and accordingly the absorbance signal is within the background (approximately 0 in Figure 4a). Appendix Figure A7 presents the data obtained for the natural ligand ephrin-A1 $\left(\mathrm{EC}_{50}=0.0027 \pm 0.0005 \mu \mathrm{M}\right)$. 
(a)

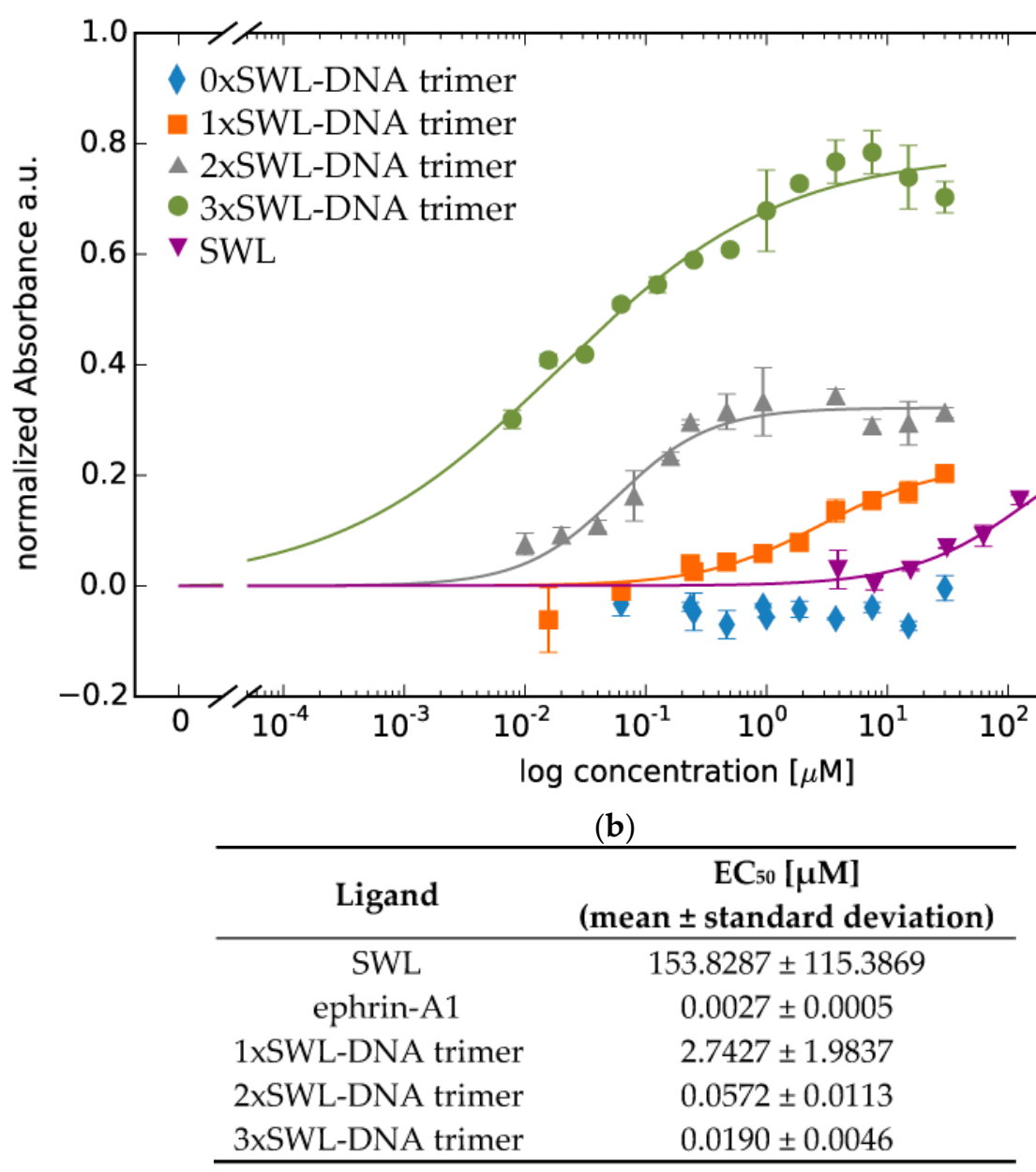

Figure 4. Quantitative analysis of phosphorylation of EphA2 receptors. Serum-starved PC-3 cells were treated with different concentrations of constructs in duplicates for $30 \mathrm{~min}$ at $37^{\circ} \mathrm{C}$. Cells were washed with $1 \times$ PBS twice and further treated according to the manufacturer's instructions. (a) Displayed data points are averages of normalized net absorbance (difference between absorbance at 520 nm versus $450 \mathrm{~nm}$ ); the net absorbance signal in the presence of different entity concentrations was normalized to the signal from treatment with $1 \times \mathrm{PBS} / 10 \mathrm{mM} \mathrm{MgCl}_{2}$ only (without any peptide or DNA constructs) resulting in normalized absorbance. Standard deviation is presented as error bars. The $\mathrm{x}$-axis indicates concentrations of the constructs in terms of DNA for 0xSWL-DNA trimer-3xSWL-DNA trimer and the concentration of the peptide for SWL. It should be understood that the $\mathrm{x}$-axis displays concentrations for whole entities not for binding entities (in this case SWL molecules). (b) $\mathrm{EC}_{50}$ values of different ligands for EphA2 receptor phosphorylation resulting from fitting (solid lines in Figure 4a, Equation (1)).

\subsection{PC-3 Cell Rounding Caused by EphA2 Activation}

Phosphorylation of EphA2 receptors is required for subsequent signaling pathways in EphA2 receptor presenting cells, therefore it is expected that multivalent presentation of the peptide on the trimeric DNA construct will lead to the most significant cell phenotype changes. As a result of downstream processes resulting from EphA2 activation, PC-3 cells retract their membrane protrusions and "round up," adopting a compact morphology [26]. The overall impact of monomeric SWL peptide or the SWL-DNA trimer displaying different numbers of peptides on cell morphology was qualitatively assessed via microscopic imaging, as seen in Figure 5. For 3xSWL-DNA trimers, a concentration of $20 \mu \mathrm{M}$, well above the measured $\mathrm{EC}_{50}$ values, was used while concentrations of the natural ligand and monovalent SWL were chosen according to previous reports. 


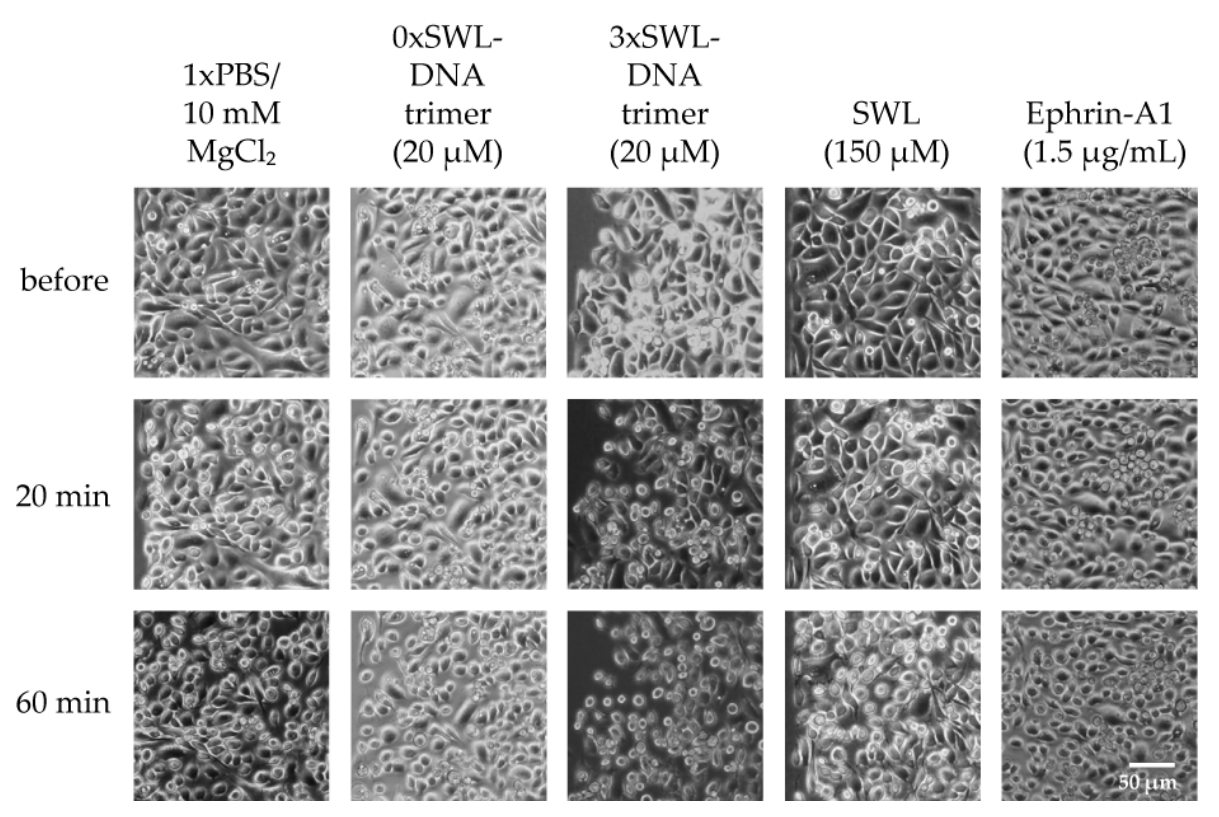

Figure 5. PC-3 cell rounding. Cells were seeded the day before and serum-starved for $4 \mathrm{~h}$ prior treatment. Samples were diluted in PBS and incubated on cells for indicated times. Cell morphology was observed and 20 and $60 \mathrm{~min}$ to account for inherent rounding effects from serum starvation.

Slight rounding of cells following starvation was a baseline effect for all samples, likely due to the lack of nutrients and medium. As expected, the most prominent differences were seen for 3xSWL-DNA trimers. At a concentration of $20 \mu \mathrm{M}$, rounding of cells was already observed after $20 \mathrm{~min}$, and was ubiquitous in the sample after $60 \mathrm{~min}$ of treatment. By contrast, after $20 \mathrm{~min}$ a significant amount of rounding beyond the likely starvation-induced effects was not significantly clear for the 1xSWL-DNA or 2xSWL-DNA structures (Figure A8). A $150 \mu \mathrm{M}$ concentration of the monomeric peptide showed no noticeable change in morphology after $20 \mathrm{~min}$ when compared to the negative controls of PBS and the DNA structure without any peptides.

In comparison to the 3xSWL-DNA structure, only moderate changes in morphology were observed to arise from the application of $1.5 \mu \mathrm{g} / \mathrm{mL}$ of the natural ephrin-A1 ligand after 20 and $60 \mathrm{~min}$. This concentration is approximately 27 times the $\mathrm{EC}_{50}$ value of $2.654 \mathrm{nM}$ as shown in Appendix Figure A7. Downstream impact on morphological phenotype is clearly suppressed even though the natural ligand did still lead to high levels of EphA2 phosphorylation, as seen in Figures 3 and A7. While seemingly contradictory, this is consistent with some previous reports where additional stimulation of the Rho-ROCK1 signaling pathway by external serum factors is necessary to cause significant levels of cell rounding following serum starvation [53].

\section{Discussion}

Here, it was shown that even simple DNA nanostructures consisting of a few strands are not only limited to serving as functional carriers for bioactive peptides such as SWL but can also enhance their activity and trigger specific downstream signaling pathways in a pinpointed manner. These rationally designed, structural scaffolds not only hold the peptides in a controlled spatial average distribution while still maintaining flexibility at the central joint to finely adjust to the arrangement of binding sites; they also preserve their functionality and provide the basis for oligovalent binding to target structures, and thus an enhanced efficacy when compared to the monovalent peptides.

The binding of Cy3-labeled SWL-DNA trimers to PC-3 cells via EphA2 receptors was analyzed using flow cytometry to determine binding curves (Figure 2). Preparation limitations impeded the production and testing of higher concentrations of the constructs. Therefore, saturation could not be achieved, likely due to the fact that EphA2 receptors are internalized upon activation [54], 
leading to an accumulation of fluorescence within the cells. In this case, saturation, if reached, would likely correspond to the actively driven depletion of expressed EphA2 receptors from the surface of the cells, rather than equilibrium kinetics. Thus, half-maximal effective concentration $\left(\mathrm{EC}_{50}\right)$ values or other binding constants could not be quantitatively determined for flow cytometry data. Nevertheless, enhanced concentration-dependent fluorescence signals for cells treated with the 3xSWL-DNA trimer compared to the 0-2 peptide variants clearly show an increased affinity due to higher-order presentation of SWL.

In a sandwich ELISA to quantify phosphorylation of tyrosine residues (Figures 3 and 4), our results underline the presence of an oligovalent effect, as 3xSWL-DNA trimers are both more potent and more efficacious than monomeric SWL peptides. Interestingly, all SWL-conjugated DNA trimers are more potent than the monovalent, unconjugated SWL peptide. SWL and 1xSWL-DNA seem to have a similar efficacy although it should be noted that the maximum effect could not be reached due to practical limitations, implying that the calculated $\mathrm{EC}_{50}$ value could be higher. However, it is clear that 1xSWL-DNA trimers can reach similar phosphorylation signals with a much lower concentration, indicating that the presence of the DNA structure improves potency. An explanation could be that the attachment of SWL to DNA already improves its stability and/or binding properties. More specifically, the larger DNA construct could shield the attached peptide from proteases, which was indeed previously implicated as a limitation for the covalently dimerized SWL variant [35]. Furthermore, DNA is known to nonspecifically stick to the outer plasma membrane of cells, which would generally increase the chances for the DNA-peptide conjugate structures to interact with any surface receptors such as EphA2 as compared to the peptide by itself.

The 2xSWL-DNA and 3xSWL-DNA constructs have a noticeably elevated performance compared to 1xSWL-DNA and SWL, as shown in Figure 4a. The attachment of two peptides on the DNA structure drastically decreases the $\mathrm{EC}_{50}$, by nearly a factor of 50 compared to 1 xSWL-DNA, which portends the influence of an oligovalent effect. This is further enhanced when 3 peptides, the suggested minimum for inducing Eph receptor clustering [42], are attached to the DNA structure. While the apparent $\mathrm{EC}_{50}$ value is only further decreased by a factor of three, the overall phosphorylation efficacy more than doubles, as compared to the monomeric peptide as well as both the mono- and bivalent DNA-peptide conjugates. The natural ligand ephrin-A1 remained most potent and efficacious when tested for EphA2 receptor phosphorylation in different concentrations (Figures A7 and 4b). As expected, 0xSWL-DNA trimer did not lead to phosphorylation at any concentration, and therefore an $\mathrm{EC}_{50}$ value was not calculated. Moreover, comparatively low signals seen for PC-3 cells treated only with PBS confirmed that even though EphA2 receptors are indeed highly expressed (indicated by the PBS control in Figure A6) they are only slightly activated.

Even though the degree of activation from even the trivalent DNA construct is greatly surpassed by that achieved by the natural ephrin-A1 ligand ( $50 \%$ higher phosphorylation levels were achieved by $250 \times$ less of the natural ligand, see Figure 3), we do point out two factors which mitigate a direct comparison. First, it is expected that a short, linear, likely flexible peptide fragment will be entropically disfavored from specifically binding to and activating its target when compared to an active polypeptide region held in a rigidly defined conformation within a folded protein. Second, as noted before, ephrin-A1 is known to bind and activate most, if not all A-type Eph receptors, several of which are expressed in PC-3 cells [55]. While the natural ligand is clearly more efficient at stimulating phosphorylation of EphA2 dimers, this does not capture the extent to which cross-stimulation of other EphA receptors interferes with downstream pathways [37,38]. Indeed, recently reported findings from Singh et al., point out that different types of ephrin ligands, including the SWL peptide used here, give rise to diverse activities of EphA2 receptor signaling [56].

This second point is of particular importance when observing the effects on cell phenotype; namely the "rounding up" of cells following treatment. While the application of the full ligand in excess of its measured $\mathrm{EC}_{50}$ value for tyrosine phosphorylation did show some moderate signs of morphological changes after $20 \mathrm{~min}$ (Figure 5) consistent with previous observations on serum-starved 
PC-3 cells [53], this was clearly surpassed by effects resulting from application of the 3xSWL-DNA constructs. Even though visual, microscopic interpretation of cell morphology is to some extent a qualitative art, this nonetheless suggests that pinpointed stimulation with the EphA2-specific peptide along with the promotion of receptor clustering is a potent trigger of this particular phenotype change. This discrepancy with the significantly more efficient tyrosine phosphorylation by the natural ligand does support the possibility of negative feedback resulting from the cross-stimulation of different EphA receptors.

More generally, the presentation of highly specific peptide fragments on simple DNA scaffolds in the way shown here potentially provides a two-pronged tool for helping to unravel the complexity of signaling pathways involving promiscuous binding between a ligand and multiple receptors [57]. Beyond the A- and B-classes of Eph receptors, the binding of a single ligand to a set of multiple receptors (or vice versa) is a common occurrence in diverse processes such as immune recognition [58], tissue and organ development [59], programmed cell death aka apoptosis $[60,61]$ and many others. The last example of cell apoptosis via activation by the TNF-related apoptosis-inducing ligand (TRAIL) ligand is a particularly compelling case for DNA-templated oligovalence; TRAIL binding to either the death (DR4, DR5) or decoy (DcR1, DcR2, osteoprotegerin) receptors can trigger or block apoptosis, respectively, with a homo-trimerization of the death receptors is a prerequisite for apoptosis stimulation. DNA-scaffolded presentation of short peptide epitopes known to be specific to a particular receptor [62, 63] would enable a systematic examination of these pathways with a pinpointed resolution in terms of biochemical pathways and degree of multimerization in signaling events.

\section{Materials and Methods}

\subsection{Synthesis of SWL-Coupled DNA Trimers}

Three partially complementary strands (Table 1 ) were purchased with $5^{\prime}$ end amino-group from Biomers.net (Ulm, Germany) and delivered in dry and HPLC-purified form.

Table 1. Oligonucleotide sequences (30 nucleotides) to form DNA trimers. Part a is complementary to $a * ; b$ to $b *$ and $c$ to $c *$. Different variations of DNA sequences were used (see footers).

\begin{tabular}{cc}
\hline Name & Sequence $\mathbf{5}^{\prime} \rightarrow \mathbf{3}^{\prime}$ \\
\hline $\mathrm{ab}$ & ACTATCTTTGGTCTATTATCTTGAGTCATC ${ }^{1,2,3,4}$ \\
$\mathrm{~b}{ }^{*} \mathrm{c}$ & GATGACTCAAGATAAACACACACACAACTA ${ }^{1,2}$ \\
$\mathrm{c}^{*} \mathrm{a}$ & TAGTTGTGTGTGTGTTAGACCAAAGATAGT ${ }^{1,2}$ \\
\hline${ }^{1}$ no modification, ${ }^{2} 5^{\prime}$ Aminolink $\mathrm{C} 6,{ }^{3}{ }^{\prime}{ }^{\prime} \mathrm{Cy} 3,{ }^{4}$ both $5^{\prime}$ Aminolink C6 and $3^{\prime} \mathrm{Cy} 3$.
\end{tabular}

The strands were resuspended in water, the concentration was determined via analysis of ultraviolet-visible spectroscopy (NanoDrop ND-1000 UV/Vis spectrophotometer from PEQLAB Biotechnologie, Erlangen, Germany) by light absorption at $260 \mathrm{~nm}$ and the DNA strands were mixed in equimolar amounts to guarantee for optimal stoichiometry and thus high yields. DNA structures were assembled at $25 \mu \mathrm{M}$ each strand in $1 \times \mathrm{PBS}$ by heating the mixture to $95^{\circ} \mathrm{C}$ for $2 \mathrm{~min}$, hybridizing at $48{ }^{\circ} \mathrm{C}$ for $15 \mathrm{~min}$ and cooling down to $4{ }^{\circ} \mathrm{C}$. For trimers carrying no, one or two peptides, amine-modified DNA strands were replaced by three, two and one unmodified strand, respectively. Unmodified DNA trimers were imaged with atomic force microscopy (AFM) (Figure A2); however, due to their small size, exact structural details were not discernible.

Folded DNA trimers were functionalized with peptides as previously described [49]. Briefly, DNA trimers were incubated with a 100-fold molar excess of DBCO-NHS esters (Jena Bioscience, Jena, Germany) in 1× PBS pH 7.4 at room temperature overnight. The next day, DBCO-coupled DNA trimers were purified from unconjugated DBCO-NHS esters by ethanol precipitation and subsequently incubated with a 20-fold molar excess of azide-containing peptide SWL (SWLAYPGAVSYRGG-Azidolysin; purchased from Peptide Specialty Laboratories, Heidelberg, 
Germany) overnight. Excess of SWL was removed via spin filtration using $1 \times \mathrm{PBS} / 10 \mathrm{mM} \mathrm{MgCl} 2$ and Amicon ${ }^{\circledR}$-Ultra-0.5 Centrifugal Filter Devices with $10 \mathrm{~K}$ MWCO (Merck Chemicals, Darmstadt, Germany) which were used according to manufacturer's instructions. Native polyacrylamide gel electrophoresis (PAGE, Figure A1) was used to analyze folding and functionalization. Matrix-assisted laser desorption/ionization-time-of-flight (MALDI-TOF) measurements were conducted to check for remains of uncoupled SWL after Amicon ${ }^{\circledR}$ purification (Figure A3).

The distance between the peptides was calculated according to well-known structural properties of double-stranded DNA. It is known that one arm consists of 15 base pairs which equals $5.1 \mathrm{~nm}$ ( $0.34 \mathrm{~nm}$ per base). By applying cosine and assuming the angle on the junction to be $120^{\circ}$, we could calculate a distance of approx. $8.8 \mathrm{~nm}$ which can vary according to buffer and salt conditions.

\subsection{Binding Assay}

Binding of SWL-DNA trimers to PC-3 cells (purchased from ATCC (ATCC ${ }^{\circledR}$ CRL-1435 ${ }^{\mathrm{TM}}$; Manassas, VA, USA) was assessed in duplicates on an Intellicyt high-throughput flow cytometer. The day before assaying, $1 \times 10^{4}$ PC-3 cells were seeded into a 96-well U-bottom plate. After serum starvation for $4 \mathrm{~h}$, cells were washed with $1 \times$ PBS, treated with serial dilutions of Cy3 labeled DNA trimers conjugated to three, two, one or no peptide SWL (3xSWL-DNA trimer, 2xSWL-DNA trimer, 1xSWL-DNA trimer, 0xSWL-DNA trimer, respectively) for $30 \mathrm{~min}$ at room temperature. Subsequently cells were rinsed with $1 \times$ PBS, detached using $0.05 \%$ trypsin-EDTA and centrifuged at $1150 \times g$ for $5 \mathrm{~min}$ at room temperature. Cells were resuspended in $1 \times \mathrm{PBS} / 1 \%(w / v)$ bovine serum albumin (BSA) and analyzed by an iQue screener (Intellicyt, Albuquerque, NM, USA).

\subsection{EphA2 Phosphorylation Assay}

Levels of EphA2 phosphorylation were determined using the DuoSet IC Human Phospho-EphA2 kit (R\&D systems, Minneapolis, MN, USA) which is based on a sandwich ELISA. Briefly, $2 \times 10^{5}$ PC-3 cells were seeded three days before the assay for the comparison of ligands. For the concentration series used to determine $\mathrm{EC}_{50}$ values, $1 \times 10^{6} \mathrm{PC}-3$ cells were seeded into 12-well culture plates one day before the assay. On the day of the experiment, cells were serum-starved for $4 \mathrm{~h}$ and treated with either 1xSWL-DNA trimer, 2xSWL-DNA trimer, 3xSWL-DNA trimer, natural ligand ephrin-A1, SWL peptide, DNA trimer only or $1 \times \mathrm{PBS} / 10 \mathrm{mM} \mathrm{MgCl}{ }_{2}$ as negative control for $30 \mathrm{~min}$ at $37^{\circ} \mathrm{C}$. Cells were lysed using $250 \mu \mathrm{L} /$ well lysis buffer (according to kit) and assayed as indicated by manufacturer's instructions. Manifold washing was conducted after every step and the whole procedure was executed at room temperature. In brief, 96-well ELISA plates carrying specific human EphA2 capture antibodies were incubated with cell lysates of afore treated PC-3 cells. This was followed by the addition of anti-phospho-tyrosine-HRP antibodies which ultimately fulfil a colorimetric reaction by conversion of 3,3',5,5'-Tetramethylbenzidine substrate solution for 25 min (ligands in Figure 4a) or 8 min (ephrin-A1 in Figure A7). This reaction was stopped by adding $2 \mathrm{~N} \mathrm{H}_{2} \mathrm{SO}_{4}$ and absorbance was measured at $450 \mathrm{~nm}$ and at $520 \mathrm{~nm}$ (infinite M1000, Tecan, Switzerland); the latter was subtracted as reference value. To normalize values from concentration series, controls (only $1 \times \mathrm{PBS} / 10 \mathrm{mM} \mathrm{MgCl} 2$ ) were subtracted, too. Data was analyzed by fitting to the equation:

$$
A=A_{\min }+\frac{\left(A_{\max }-A_{\min }\right)}{1+\left(\frac{x}{E C_{50}}\right)^{-b}}
$$

where $A$ is the observed absorbance, $A_{\min }$ and $A_{\max }$ are minimal and maximal absorbance respectively, and $b$ is the Hill coefficient.

\subsection{Cell Rounding Assays}

PC-3 cells were checked for changes in cell morphology upon activation of EphA2 receptors and following signaling pathways. Briefly, sub-confluent PC-3 cells in 96-well plates were serum-starved 
for $4 \mathrm{~h}$ and then incubated for up to $1 \mathrm{~h}$ with either 3xSWL-DNA trimer $(20 \mu \mathrm{M})$, natural ligand ephrin-A1 $(1.5 \mu \mathrm{g} / \mathrm{mL})$, SWL peptide $(150 \mu \mathrm{M})$, DNA trimer only $(20 \mu \mathrm{M})$ or $1 \times \mathrm{PBS} / 10 \mathrm{mM} \mathrm{MgCl} 2$ as control. Microscopic images of PC-3 cells were taken using a Leica DM IL microscope with 10× objective to assess cell contraction and rounding.

Author Contributions: Conceptualization, C.M. and D.M.S.; Data curation, C.M.; Formal analysis, C.M. and M.S.; Funding acquisition, D.M.S.; Methodology, C.M., J.S.L. and D.M.S.; Project administration, D.M.S.; Supervision, D.M.S.; Validation, C.M., M.S. and D.M.S.; Visualization, C.M. and M.S.; Writing-original draft, C.M.; Writing-review \& editing, J.S.L. and D.M.S.

Funding: This research was funded by Fraunhofer Attract funding (grant number: 601683) and the European Regional Development Fund (grant number 100185665). The APC was funded by the University of Leipzig within the program of Open Access Publishing.

Acknowledgments: We acknowledge Arndt Wilcke for providing access to the mass spectrometer. We thank Oliver Otto and Jochen Guck for helpful discussions.

Conflicts of Interest: The authors declare no conflict of interest.

\section{Abbreviations}

0xSWL-DNA trimer
1xSWL-DNA trimer
2xSWL-DNA trimer
3xSWL-DNA trimer
AFM
BSA
DBCO
EC50
ELISA
Eph receptor
ephrin
FCS
HPLC
MALDI-TOF
MW
MWCO
NHS
PAGE
PE
PBS
RTK
TRAIL

DNA trimer

One SWL peptide coupled to one DNA trimer

Two SWL peptides coupled to one DNA trimer

Three SWL peptides coupled to one DNA trimer atomic force microscopy

bovine serum albumin

dibenzylcyclooctyne

Half-maximal effective concentration

Enzyme-linked Immunosorbent Assay

Erythropoietin-producing hepatocellular carcinoma receptor

Eph family receptor- interacting protein

fetal calf serum

high-pressure liquid chromatography

matrix-assisted laser desorption/ionization-time-of-flight

molecular weight

molecular weight cut off

$N$-hydroxysuccinimide

polyacrylamide gel electrophoresis

Phycoerythrin

phosphate-buffered saline

receptor tyrosine kinase

TNF-related apoptosis-inducing ligand 


\section{Appendix A}

Analysis of production of DNA trimers coupled to SWL peptides via native PAGE.

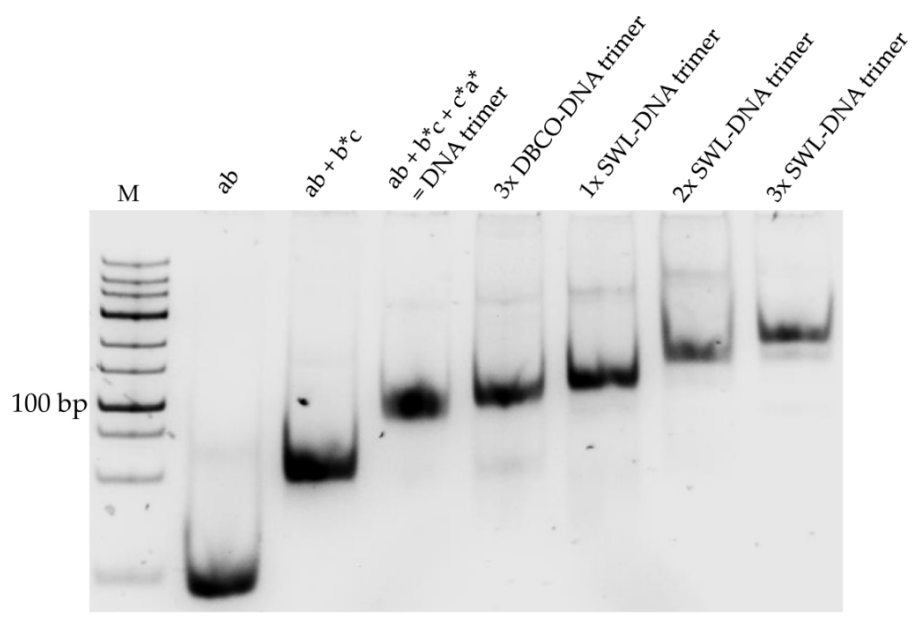

Figure A1. 10\% $(v / v)$ native PAGE showing the assembly of DNA trimers and addition of SWL peptides. Three partially complementary DNA strands $\left(a b, b{ }^{*} c\right.$ and $\left.c{ }^{*} a{ }^{*}\right)$ were self-assembled to DNA trimers $\left(\mathrm{ab}+\mathrm{b}{ }^{*} \mathrm{c}+\mathrm{c}^{*} \mathrm{a} *\right.$ DNA trimer). Trimers were modified with three DBCO molecules $(3 \times$ DBCO-DNA trimer) for the addition of three SWL peptides (3xSWL-DNA trimer). By mixing DBCOand unmodified strands, trimers containing 1xSWL (1xSWL-DNA trimer) and 2xSWL (2xSWL-DNA trimer) were produced. PAGE gel was stained with SYBR ${ }^{\circledR}$ Gold Nucleic Acid Gel Stain (Thermo Fisher Scientific, Waltham, MA, USA) and imaged under UV light. M = GeneRulerTM Low Range DNA Ladder (Thermo Fisher Scientific, Waltham, MA, USA) serves as control, not as ruler.

Analysis of construction of DNA trimer via AFM.

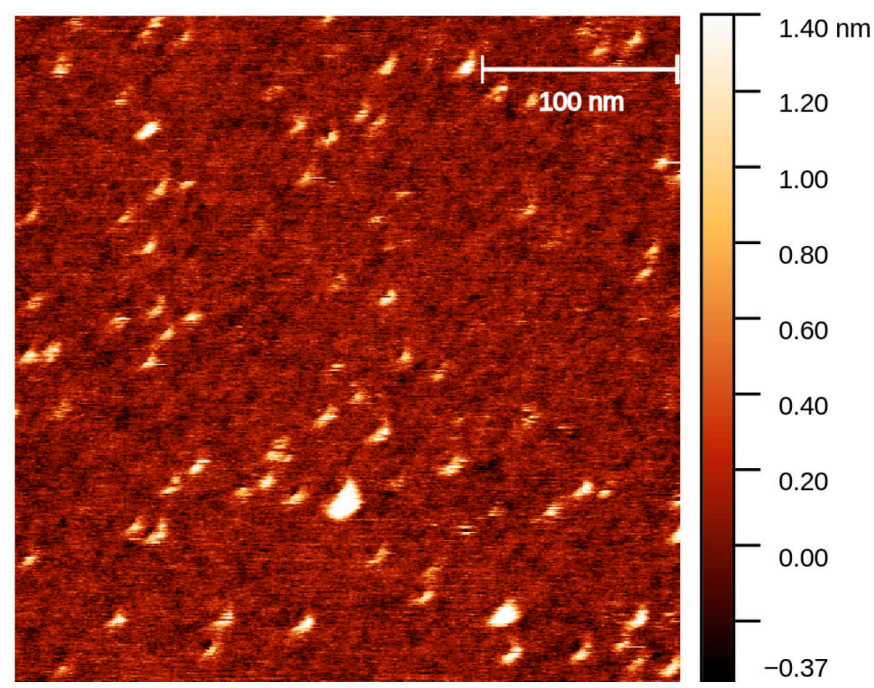

Figure A2. AFM image of unmodified DNA trimers. Freshly cleaved mica surface glued onto a microscopic slide was incubated with $100 \mu \mathrm{L}$ Poly-L-ornithin for $10 \mathrm{~min}$ at room temperature. Subsequently, the mica was washed three times with $1 \times \mathrm{TE} / 10 \mathrm{mM} \mathrm{MgCl}$ buffer followed by application of $20 \mu \mathrm{L}$ of $20 \mu \mathrm{M}$ DNA trimer for $15 \mathrm{~min}$. A plastic ring was glued around the mica to create a chamber that was filled with $1 \times \mathrm{TE} / 10 \mathrm{mM} \mathrm{MgCl}_{2}$ buffer to enable measurements in fluid tapping mode. AFM height image was recorded using an SNL-10 (C) cantilever (Bruker AFM Probes, UK) and the atomic force microscope NanoWizard 3.0. (JPK, Berlin, Germany). While the exact trimeric structure is not discernible due to limits in imaging structures of this size, the spots correspond to expected size for trimers of approx. 5-10 $\mathrm{nm}$ in diameter. 
Analysis of oligonucleotides coupled to SWL peptides via MALDI-TOF.

Mass spectra serve as raw estimation and should not be understood as calculated ratios.

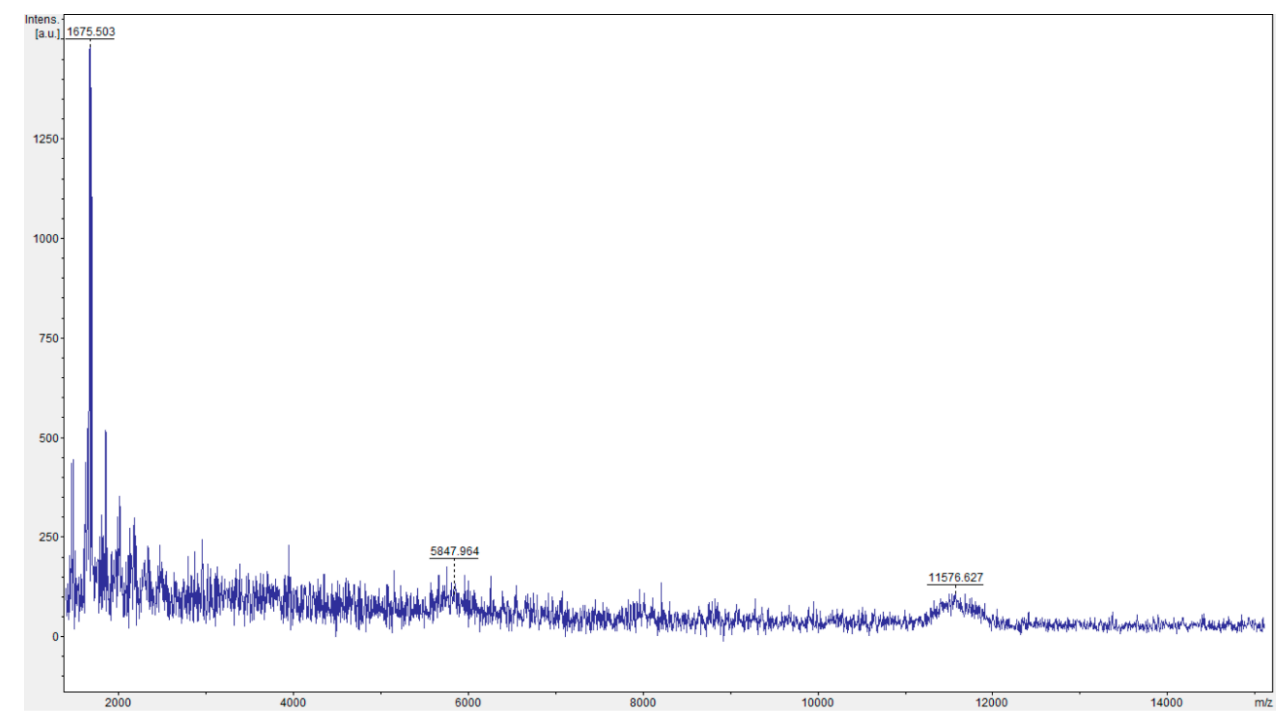

(a)

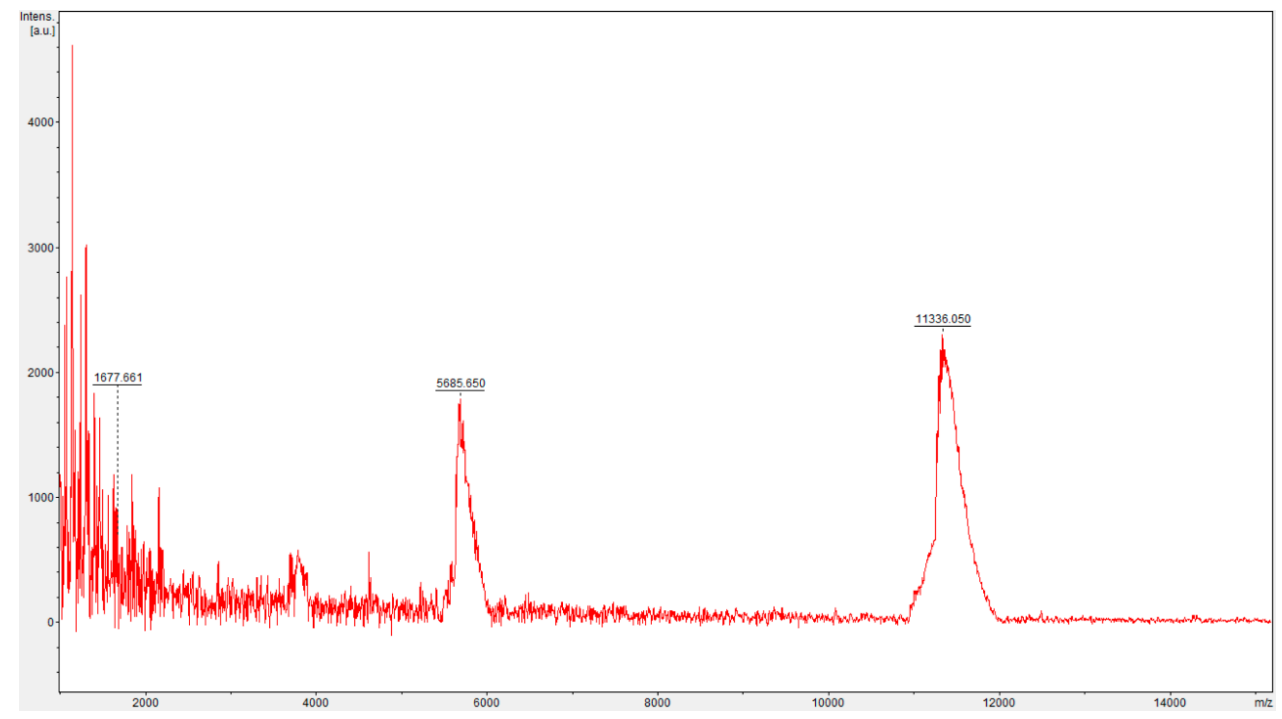

(b)

Figure A3. Comparison of mass spectra of oligonucleotides coupled to one SWL peptide. Mass spectra were obtained by using an Autoflex Speed mass spectrometer (Bruker Daltonik, Bremen, Germany) with 3-hydroxypicolinic acid matrix. (a) SWL-coupled oligonucleotides (30 nucleotides; expected mass $11.3 \mathrm{kDa}$ ) before purification with Amicon ${ }^{\circledR} 3 \mathrm{~K}$ filter. Peak at $11.5 \mathrm{kDa}$ confirms the covalent conjugation of SWL to oligonucleotides (double ionized peak at $5.8 \mathrm{kDa}$ ). Oligonucleotides, that were not coupled to SWL peptide, could not be detected (peak would be at $9.3 \mathrm{kDa}$ ). Peak at $1.7 \mathrm{kDa}$ corresponds to free SWL peptide. This peak is relatively high in comparison to both DNA peaks. (b) Mass spectra of Amicon ${ }^{\circledR} 3 \mathrm{~K}$ purified SWL-oligonucleotides. The ratio of SWL-oligonucleotides to uncoupled SWL shifted remarkably; the peak for free SWL is within the noise range whereas higher peaks are visible for DNA-SWL conjugates. 
Stability of SWL-DNA trimers in 50\% $(v / v)$ serum and on cells.

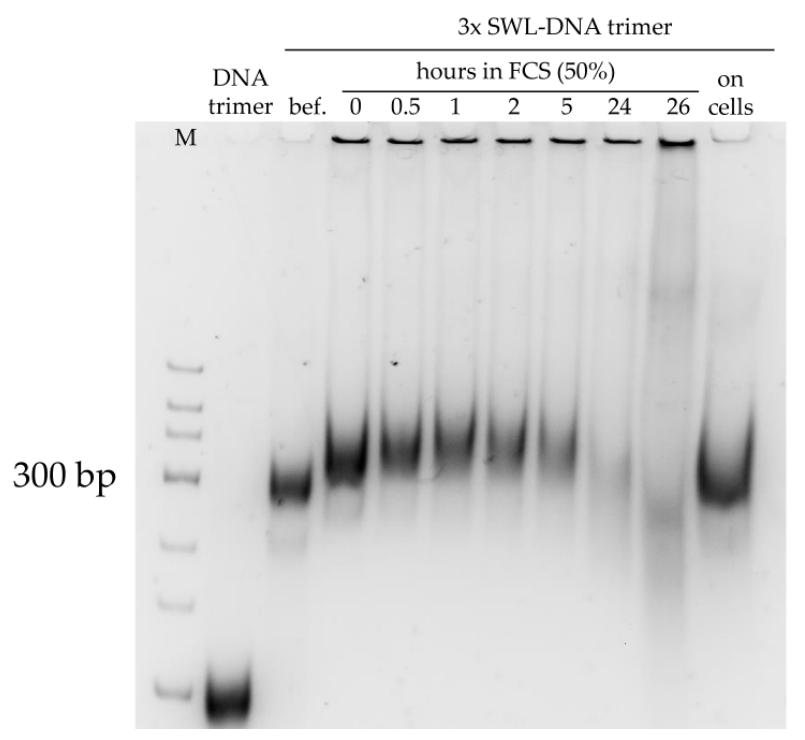

Figure A4. Stability of 3xSWL-DNA trimers in 50\% $(v / v)$ fetal calf serum (FCS) and incubated with PC-3 cells at $37^{\circ} \mathrm{C}$. Constructs were incubated in 50\% $(v / v)$ FCS over time, analyzed on $10 \%(v / v)$ native PAGE and stained with $\mathrm{SYBR}^{\circledR}$ Gold Nucleic Acid Gel Stain. Unmodified DNA trimers serve as control. Sample "bef." = 3xSWL-DNA trimers before addition of FCS, sample is in $1 \times$ PBS $/ 10 \mathrm{mM}$ $\mathrm{MgCl}_{2}$. Addition of FCS led to upward shift in gel. Structures were stable over $5 \mathrm{~h}$ and degraded after $24 \mathrm{~h}$. When incubated with PC-3 cells in serum-free medium, 3xSWL-DNA trimers were stable for at least $24 \mathrm{~h}$ (far right band).

\section{Appendix B}

Confirmation EphA2 receptor expression by PE anti-human EphA2.

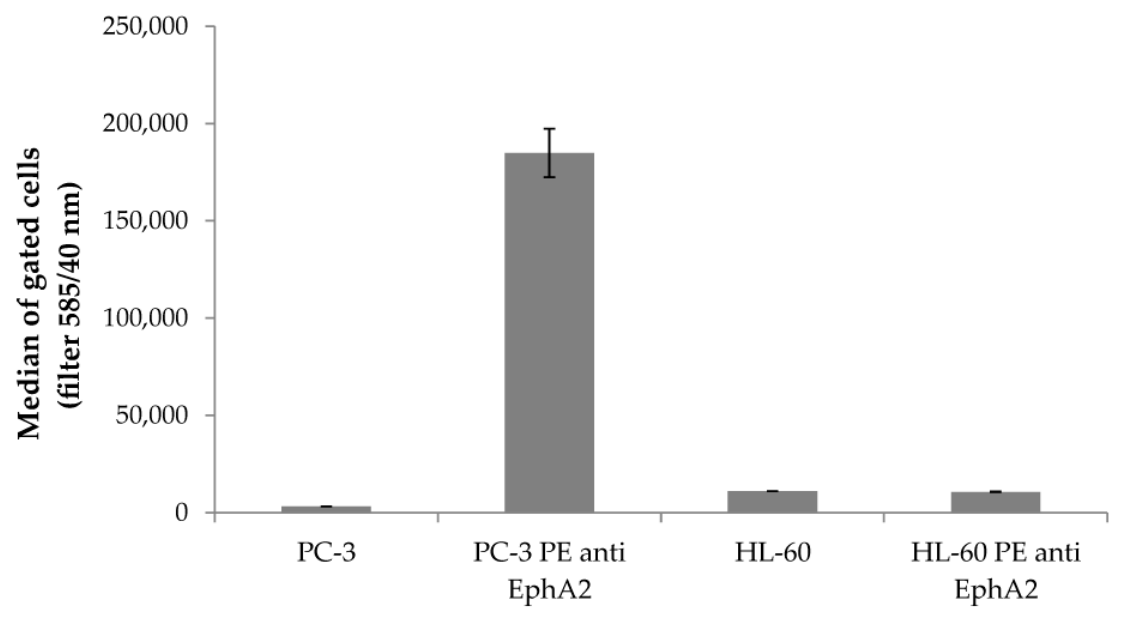

Figure A5. Flow cytometry analysis of EphA2 expression. Solubilized PC-3 cells at a concentration of $4 \times 10^{4}$ were incubated with PE anti-human EphA2 antibody (Biolegend, Fell, Germany) according to manufacturer's instructions for $30 \mathrm{~min}$ at $4{ }^{\circ} \mathrm{C}$. Cells were washed with $1 \times$ PBS twice, trypsinized using $0.05 \%$ trypsin-EDTA, collected by centrifugation and treated as described in 4.2 . As negative control, HL-60 suspension cells which theoretically do not express EphA2 receptors were washed with $1 \times$ PBS and treated as described in 4.2, too. Samples were analyzed using an iQue screener (Intellicyt, Albuquerque, NM, USA). Displayed are average values of gated cells with standard deviation presented as error bars. PC-3 cells treated with PE anti-human EphA2 antibody showed enhanced fluorescence signals compared to untreated PC-3 cells. Fluorescence signals from HL-60 cells were not elevated which confirms that these do not express EphA2 receptors. 
Raw flow cytometry data of SWL-DNA trimers binding to PC-3 cells.

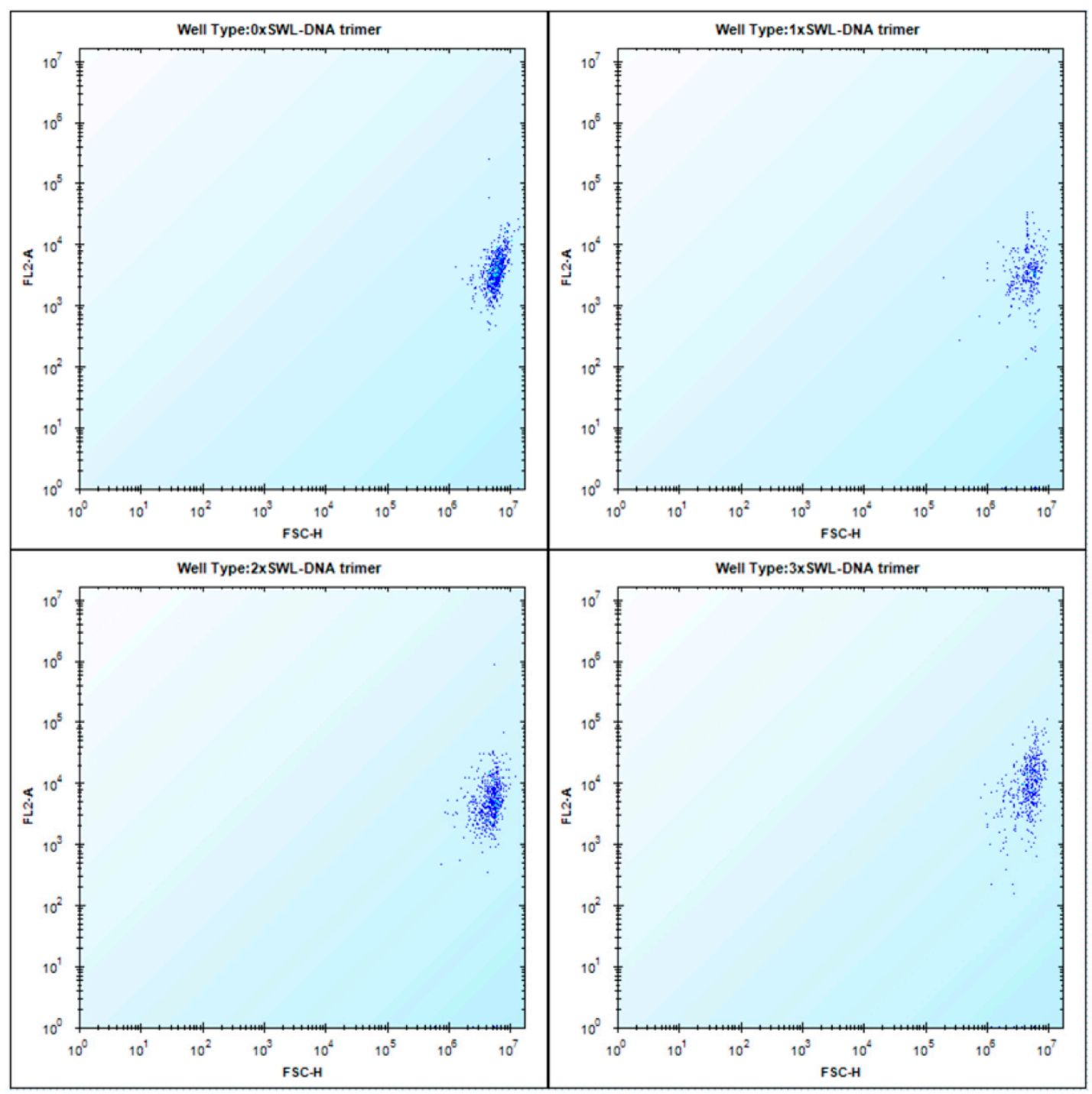

Figure A6. Flow cytometry raw images of SWL-functionalized DNA trimers to PC-3 cells. Cells were treated as described in 4.2 and analyzed using an iQue screener (Intellicyt). Elevated signals at up to intensities of $10^{5}$ in FL2-A (filter 585/40 nm) indicated enhanced binding of 3xSWL-DNA trimers to PC-3 cells (lower right image). 
Phosphorylation Assay for ephrin-A1.

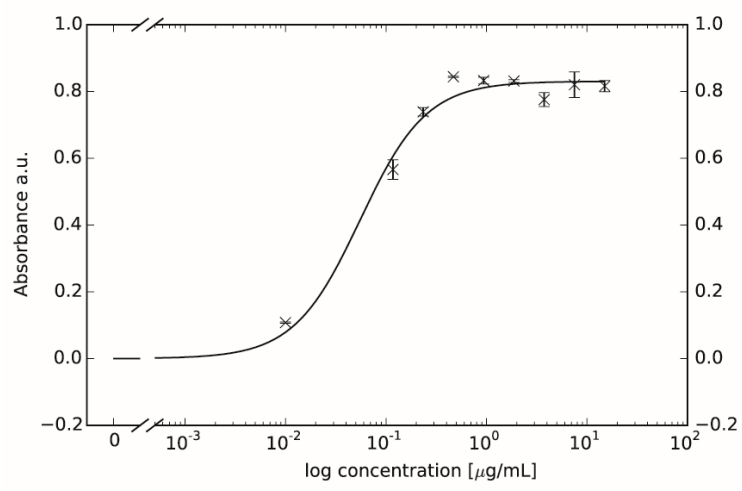

Figure A7. Dose-Response curve of EphA2 phosphorylation due to different concentration of ephrin-A1 ligand. Displayed values are averages of net absorbance (difference between absorbance at $520 \mathrm{~nm}$ versus $450 \mathrm{~nm}$ ) with standard deviation presented as error bars. The calculated $\mathrm{EC}_{50}$ value is $0.0552 \pm 0.0103 \mu \mathrm{g} / \mathrm{mL}$ which equals $2.65 \mathrm{nM}$.

PC-3 cell rounding caused by EphA2 activation from treatment with 1xSWL-DNA trimer and 2xSWLDNA trimer.

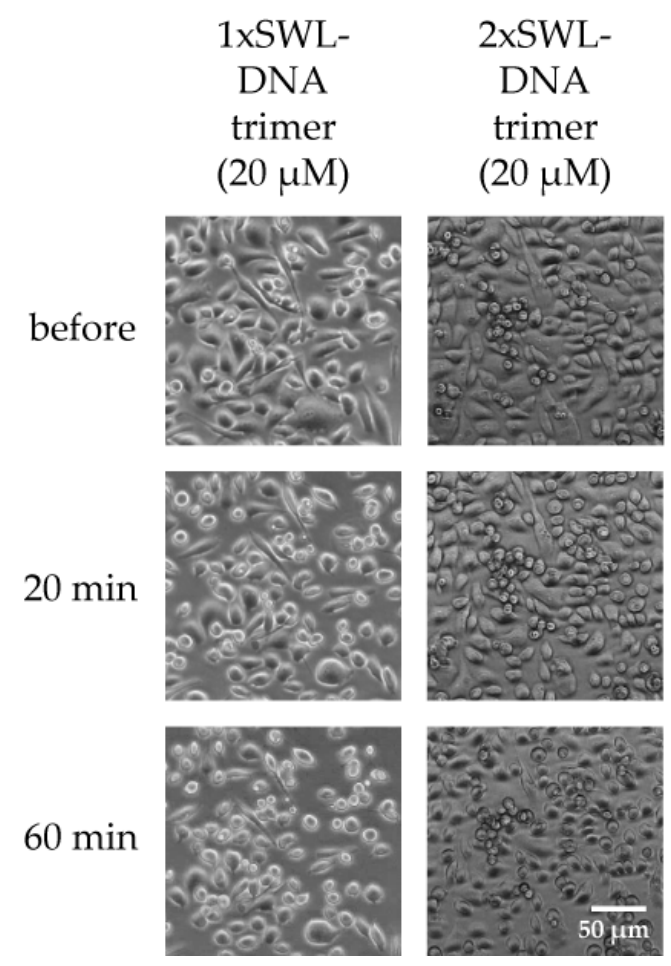

Figure A8. PC-3 cell rounding. Cells were seeded the day before and serum-starved for $4 \mathrm{~h}$ prior treatment. Samples were diluted in PBS and incubated on cells for indicated times. Cell morphology was observed and 20 and $60 \mathrm{~min}$ to account for inherent rounding effects from serum starvation.

\section{References}

1. Seeman, N.C. Nucleic acid junctions and lattices. J. Theor. Biol. 1982, 99, 237-247. [CrossRef]

2. Rothemund, P.W.K. Folding DNA to create nanoscale shapes and patterns. Nature 2006, 440, $297-302$. [CrossRef] [PubMed]

3. Yan, H.; LaBean, T.H.; Feng, L.; Reif, J.H. Directed nucleation assembly of DNA tile complexes for barcode-patterned lattices. Proc. Natl. Acad. Sci. USA 2003, 100, 8103-8108. [CrossRef] [PubMed] 
4. Goodman, R.P.; Schaap, I.A.T.; Tardin, C.F.; Erben, C.M.; Berry, R.M.; Schmidt, C.F.; Turberfield, A.J. Rapid chiral assembly of rigid DNA building blocks for molecular nanofabrication. Science 2005, 310, 1661-1665. [CrossRef] [PubMed]

5. Yin, P.; Hariadi, R.F.; Sahu, S.; Choi, H.M.T.; Park, S.H.; LaBean, T.H.; Reif, J.H. Programming DNA Tube Circumferences. Science 2008, 321, 824-826. [CrossRef] [PubMed]

6. Ke, Y.; Ong, L.L.; Shih, W.M.; Yin, P. Three-Dimensional Structures Self-Assembled from DNA Bricks. Science 2012, 338, 1177-1183. [CrossRef] [PubMed]

7. Sprengel, A.; Lill, P.; Stegemann, P.; Bravo-Rodriguez, K.; Schöneweiß, E.-C.; Merdanovic, M.; Gudnason, D.; Aznauryan, M.; Gamrad, L.; Barcikowski, S.; et al. Tailored protein encapsulation into a DNA host using geometrically organized supramolecular interactions. Nat. Commun. 2017, 8, 14472. [CrossRef] [PubMed]

8. Shaw, A.; Lundin, V.; Petrova, E.; Fördos, F.; Benson, E.; Al-Amin, A.; Herland, A.; Blokzijl, A.; Högberg, B.; Teixeira, A.I. Spatial control of membrane receptor function using ligand nanocalipers. Nat. Methods 2014, 11, 841-846. [CrossRef] [PubMed]

9. Zhao, Y.; Shaw, A.; Zeng, X.; Benson, E.; Nyström, A.M.; Högberg, B. DNA origami delivery system for cancer therapy with tunable release properties. ACS Nano 2012, 6, 8684-8691. [CrossRef] [PubMed]

10. Lee, H.; Lytton-Jean, A.K.R.; Chen, Y.; Love, K.T.; Park, A.I.; Karagiannis, E.D.; Sehgal, A.; Querbes, W.; Zurenko, C.S.; Jayaraman, M.; et al. Molecularly self-assembled nucleic acid nanoparticles for targeted in vivo siRNA delivery. Nat. Nanotechnol. 2012, 7, 389-393. [CrossRef] [PubMed]

11. Douglas, S.M.; Bachelet, I.; Church, G.M. A logic-gated nanorobot for targeted transport of molecular payloads. Science 2012, 335, 831-834. [CrossRef] [PubMed]

12. Wu, C.; Han, D.; Chen, T.; Peng, L.; Zhu, G.; You, M.; Qiu, L.; Sefah, K.; Zhang, X.; Tan, W. Building a multifunctional aptamer-based DNA nanoassembly for targeted cancer therapy. J. Am. Chem. Soc. 2013, 135, 18644-18650. [CrossRef] [PubMed]

13. Jiang, Q.; Song, C.; Nangreave, J.; Liu, X.; Lin, L.; Qiu, D.; Wang, Z.-G.; Zou, G.; Liang, X.; Yan, H.; et al. DNA origami as a carrier for circumvention of drug resistance. J. Am. Chem. Soc. 2012, 134, 13396-13403. [CrossRef] [PubMed]

14. Kim, K.-R.; Kim, D.-R.; Lee, T.; Yhee, J.Y.; Kim, B.-S.; Kwon, I.C.; Ahn, D.-R. Drug delivery by a self-assembled DNA tetrahedron for overcoming drug resistance in breast cancer cells. Chem. Commun. 2013, 49, 2010. [CrossRef] [PubMed]

15. Pasquale, E.B. Eph receptor signalling casts a wide net on cell behaviour. Nat. Rev. Mol. Cell Biol. 2005, 6, 462-475. [CrossRef] [PubMed]

16. Pasquale, E.B. Eph-ephrin promiscuity is now crystal clear. Nat. Neurosci. 2004, 7, 417-418. [CrossRef] [PubMed]

17. Blits-Huizinga, C.T.; Nelersa, C.M.; Malhotra, A.; Liebl, D.J. Ephrins and their receptors: Binding versus biology. IUBMB Life 2004, 56, 257-265. [CrossRef] [PubMed]

18. Zelinski, D.P.; Zantek, N.D.; Stewart, J.C.; Irizarry, A.R.; Kinch, M.S. EphA2 overexpression causes tumorigenesis of mammary epithelial cells. Cancer Res. 2001, 61, 2301-2306. [PubMed]

19. Walker-Daniels, J.; Coffman, K.; Azimi, M.; Rhim, J.S.; Bostwick, D.G.; Snyder, P.; Kerns, B.J.; Waters, D.J.; Kinch, M.S. Overexpression of the EphA2 tyrosine kinase in prostate cancer. Prostate 1999, 41, 275-280. [CrossRef]

20. Thaker, P.H.; Deavers, M.; Celestino, J.; Thornton, A.; Fletcher, M.S.; Landen, C.N.; Kinch, M.S.; Kiener, P.A.; Sood, A.K. EphA2 expression is associated with aggressive features in ovarian carcinoma. Clin. Cancer Res. 2004, 10, 5145-5150. [CrossRef] [PubMed]

21. Kinch, M.S.; Moore, M.-B.; Harpole, D.H. Predictive value of the EphA2 receptor tyrosine kinase in lung cancer recurrence and survival. Clin. Cancer Res. 2003, 9, 613-618. [PubMed]

22. Miao, H.; Li, D.-Q.; Mukherjee, A.; Guo, H.; Petty, A.; Cutter, J.; Basilion, J.P.; Sedor, J.; Wu, J.; Danielpour, D.; et al. EphA2 mediates ligand-dependent inhibition and ligand-independent promotion of cell migration and invasion via a reciprocal regulatory loop with Akt. Cancer Cell 2009, 16, 9-20. [CrossRef] [PubMed]

23. Barquilla, A.; Pasquale, E.B. Eph receptors and ephrins: Therapeutic opportunities. Annu. Rev. Pharmacol. Toxicol. 2015, 55, 465-487. [CrossRef] [PubMed]

24. Miao, H.; Wei, B.-R.; Peehl, D.M.; Li, Q.; Alexandrou, T.; Schelling, J.R.; Rhim, J.S.; Sedor, J.R.; Burnett, E.; Wang, B. Activation of EphA receptor tyrosine kinase inhibits the Ras/MAPK pathway. Nat. Cell Biol. 2001, 3, 527-530. [CrossRef] [PubMed] 
25. Yang, N.-Y.; Fernandez, C.; Richter, M.; Xiao, Z.; Valencia, F.; Tice, D.A.; Pasquale, E.B. Crosstalk of the EphA2 receptor with a serine/threonine phosphatase suppresses the Akt-mTORC1 pathway in cancer cells. Cell. Signal. 2011, 23, 201-212. [CrossRef] [PubMed]

26. Miao, H.; Burnett, E.; Kinch, M.; Simon, E.; Wang, B. Activation of EphA2 kinase suppresses integrin function and causes focal-adhesion-kinase dephosphorylation. Nat. Cell Biol. 2000, 2, 62-69. [CrossRef] [PubMed]

27. Jackson, D.; Gooya, J.; Mao, S.; Kinneer, K.; Xu, L.; Camara, M.; Fazenbaker, C.; Fleming, R.; Swamynathan, S.; Meyer, D.; et al. A Human Antibody-Drug Conjugate Targeting EphA2 Inhibits Tumor Growth In vivo. Cancer Res. 2008, 68, 9367-9374. [CrossRef] [PubMed]

28. Petty, A.; Myshkin, E.; Qin, H.; Guo, H.; Miao, H.; Tochtrop, G.P.; Hsieh, J.-T.; Page, P.; Liu, L.; Lindner, D.J.; et al. A Small Molecule Agonist of EphA2 Receptor Tyrosine Kinase Inhibits Tumor Cell Migration in Vitro and Prostate Cancer Metastasis in Vivo. PLoS ONE 2012, 7, e42120. [CrossRef] [PubMed]

29. Wang, S.; Placzek, W.J.; Stebbins, J.L.; Mitra, S.; Noberini, R.; Koolpe, M.; Zhang, Z.; Dahl, R.; Pasquale, E.B.; Pellecchia, M. Novel Targeted System To Deliver Chemotherapeutic Drugs to EphA2-Expressing Cancer Cells. J. Med. Chem. 2012, 55, 2427-2436. [CrossRef] [PubMed]

30. Tandon, M.; Vemula, S.V.; Mittal, S.K. Emerging strategies for EphA2 receptor targeting for cancer therapeutics. Expert Opin. Ther. Targets 2011, 15, 31-51. [CrossRef] [PubMed]

31. Liu, Y.; Lan, X.; Wu, T.; Lang, J.; Jin, X.; Sun, X.; Wen, Q.; An, R. 99mTc-labeled SWL specific peptide for targeting EphA2 receptor. Nucl. Med. Biol. 2014, 41, 450-456. [CrossRef] [PubMed]

32. Cai, W.; Ebrahimnejad, A.; Chen, K.; Cao, Q.; Li, Z.-B.; Tice, D.A.; Chen, X. Quantitative radioimmunoPET imaging of EphA2 in tumor-bearing mice. Eur. J. Nucl. Med. Mol. Imaging 2007, 34, 2024-2036. [CrossRef] [PubMed]

33. Koolpe, M.; Dail, M.; Pasquale, E.B. An ephrin mimetic peptide that selectively targets the EphA2 receptor. J. Biol. Chem. 2002, 277, 46974-46979. [CrossRef] [PubMed]

34. Mitra, S.; Duggineni, S.; Koolpe, M.; Zhu, X.; Huang, Z.; Pasquale, E.B. Structure-activity relationship analysis of peptides targeting the EphA2 receptor. Biochemistry 2010, 49, 6687-6695. [CrossRef] [PubMed]

35. Duggineni, S.; Mitra, S.; Lamberto, I.; Han, X.; Xu, Y.; An, J.; Pasquale, E.B.; Huang, Z. Design and Synthesis of Potent Bivalent Peptide Agonists Targeting the EphA2 Receptor. ACS Med. Chem. Lett. 2013, 4. [CrossRef] [PubMed]

36. Coulthard, M.G.; Morgan, M.; Woodruff, T.M.; Arumugam, T.V.; Taylor, S.M.; Carpenter, T.C.; Lackmann, M.; Boyd, A.W. Eph/ephrin signaling in injury and inflammation. Am. J. Pathol. 2012, 181, 1493-1503. [CrossRef] [PubMed]

37. Falivelli, G.; Lisabeth, E.M.; Rubio de la Torre, E.; Perez-Tenorio, G.; Tosato, G.; Salvucci, O.; Pasquale, E.B. Attenuation of eph receptor kinase activation in cancer cells by coexpressed ephrin ligands. PLoS ONE 2013, 8, e81445. [CrossRef] [PubMed]

38. Astin, J.W.; Batson, J.; Kadir, S.; Charlet, J.; Persad, R.A.; Gillatt, D.; Oxley, J.D.; Nobes, C.D. Competition amongst Eph receptors regulates contact inhibition of locomotion and invasiveness in prostate cancer cells. Nat. Cell Biol. 2010, 12, 1194-1204. [CrossRef] [PubMed]

39. Fasting, C.; Schalley, C.; Weber, M.; Seitz, O.; Hecht, S.; Koksch, B.; Dernedde, J.; Graf, C.; Knapp, E.-W.; Haag, R. Multivalency as a chemical organization and action principle. Angew. Chem. Int. Ed. Engl. 2012, 51, 10472-10498. [CrossRef] [PubMed]

40. Stein, E.; Lane, A.A.; Cerretti, D.P.; Schoecklmann, H.O.; Schroff, A.D.; Van Etten, R.L.; Daniel, T.O. Eph receptors discriminate specific ligand oligomers to determine alternative signaling complexes, attachment, and assembly responses. Genes Dev. 1998, 12, 667-678. [CrossRef] [PubMed]

41. Smith, F.M.; Vearing, C.; Lackmann, M.; Treutlein, H.; Himanen, J.; Chen, K.; Saul, A.; Nikolov, D.; Boyd, A.W. Dissecting the EphA3/Ephrin-A5 Interactions Using a Novel Functional Mutagenesis Screen. J. Biol. Chem. 2004, 279, 9522-9531. [CrossRef] [PubMed]

42. Xu, Q.; Lin, W.-C.; Petit, R.S.; Groves, J.T. EphA2 Receptor Activation by Monomeric Ephrin-A1 on Supported Membranes. Biophys. J. 2011, 101, 2731-2739. [CrossRef] [PubMed]

43. Funke, J.J.; Dietz, H. Placing molecules with Bohr radius resolution using DNA origami. Nat. Nanotechnol. 2016, 11, 47-52. [CrossRef] [PubMed]

44. Keum, J.-W.; Bermudez, H. Enhanced resistance of DNA nanostructures to enzymatic digestion. Chem. Commun. 2009, 7036-7038. [CrossRef] [PubMed] 
45. Kolb, H.C.; Finn, M.G.; Sharpless, K.B. Click Chemistry: Diverse Chemical Function from a Few Good Reactions. Angew. Chem. Int. Ed. Engl. 2001, 40, 2004-2021. [CrossRef]

46. Baskin, J.M.; Prescher, J.A.; Laughlin, S.T.; Agard, N.J.; Chang, P.V.; Miller, I.A.; Lo, A.; Codelli, J.A.; Bertozzi, C.R. Copper-free click chemistry for dynamic in vivo imaging. Proc. Natl. Acad. Sci. USA 2007, 104, 16793-16797. [CrossRef] [PubMed]

47. Jewett, J.C.; Bertozzi, C.R. Cu-free click cycloaddition reactions in chemical biology. Chem. Soc. Rev. 2010, 39, 1272. [CrossRef] [PubMed]

48. Agard, N.J.; Prescher, J.A.; Bertozzi, C.R. A Strain-Promoted [3 + 2] Azide-Alkyne Cycloaddition for Covalent Modification of Biomolecules in Living Systems. J. Am. Chem. Soc. 2004, 126, 15046-15047. [CrossRef] [PubMed]

49. Lorenz, J.S.; Schnauß, J.; Glaser, M.; Sajfutdinow, M.; Schuldt, C.; Käs, J.A.; Smith, D.M. Synthetic Transient Crosslinks Program the Mechanics of Soft, Biopolymer-Based Materials. Adv. Mater. 2018, 30, 1706092. [CrossRef] [PubMed]

50. Himanen, J.P.; Yermekbayeva, L.; Janes, P.W.; Walker, J.R.; Xu, K.; Atapattu, L.; Rajashankar, K.R.; Mensinga, A.; Lackmann, M.; Nikolov, D.B.; et al. Architecture of Eph receptor clusters. Proc. Natl. Acad. Sci. USA 2010, 107, 10860-10865. [CrossRef] [PubMed]

51. Mukai, M.; Suruga, N.; Saeki, N.; Ogawa, K. EphA receptors and ephrin-A ligands are upregulated by monocytic differentiation/maturation and promote cell adhesion and protrusion formation in HL60 monocytes. BMC Cell Biol. 2017, 18, 28. [CrossRef] [PubMed]

52. Sebaugh, J.L. Guidelines for accurate EC50/IC50 estimation. Pharm. Stat. 2011, 10, 128-134. [CrossRef] [PubMed]

53. Huang, X.; Wu, D.; Jin, H.; Stupack, D.; Wang, J.Y.J. Induction of cell retraction by the combined actions of Abl-CrkII and Rho-ROCK1 signaling. J. Cell Biol. 2008, 183, 711-723. [CrossRef] [PubMed]

54. Walker-Daniels, J.; Riese, D.J.; Kinch, M.S. c-Cbl-dependent EphA2 protein degradation is induced by ligand binding. Mol. Cancer Res. 2002, 1, 79-87. [PubMed]

55. Fox, B.P.; Tabone, C.J.; Kandpal, R.P. Potential clinical relevance of Eph receptors and ephrin ligands expressed in prostate carcinoma cell lines. Biochem. Biophys. Res. Commun. 2006, 342, 1263-1272. [CrossRef] [PubMed]

56. Singh, D.R.; Kanvinde, P.; King, C.; Pasquale, E.B.; Hristova, K. The EphA2 receptor is activated through induction of distinct, ligand-dependent oligomeric structures. Commun. Biol. 2018, 1, 15. [CrossRef] [PubMed]

57. Schreiber, G.; Keating, A.E. Protein binding specificity versus promiscuity. Curr. Opin. Struct. Biol. 2011, 21, 50-61. [CrossRef] [PubMed]

58. Eisen, H.N.; Hou, X.H.; Shen, C.; Wang, K.; Tanguturi, V.K.; Smith, C.; Kozyrytska, K.; Nambiar, L.; McKinley, C.A.; Chen, J.; et al. Promiscuous binding of extracellular peptides to cell surface class I MHC protein. Proc. Natl. Acad. Sci. USA 2012, 109, 4580-4585. [CrossRef] [PubMed]

59. Mueller, T.D.; Nickel, J. Promiscuity and specificity in BMP receptor activation. FEBS Lett. 2012, 586, 1846-1859. [CrossRef] [PubMed]

60. Ashkenazi, A. Death Receptors: Signaling and Modulation. Science 1998, 281, 1305-1308. [CrossRef] [PubMed]

61. Wajant, H.; Pfizenmaier, K.; Scheurich, P. TNF-related apoptosis inducing ligand (TRAIL) and its receptors in tumor surveillance and cancer therapy. Apoptosis 2002, 7, 449-459. [CrossRef] [PubMed]

62. Okochi, M.; Nakanishi, M.; Kato, R.; Kobayashi, T.; Honda, H. High-throughput screening of cell death inducible short peptides from TNF-related apoptosis-inducing ligand sequence. FEBS Lett. 2006, 580, 885-889. [CrossRef] [PubMed]

63. Tur, V.; van der Sloot, A.M.; Reis, C.R.; Szegezdi, E.; Cool, R.H.; Samali, A.; Serrano, L.; Quax, W.J. DR4-selective Tumor Necrosis Factor-related Apoptosis-inducing Ligand (TRAIL) Variants Obtained by Structure-based Design. J. Biol. Chem. 2008, 283, 20560-20568. [CrossRef] [PubMed]

(C) 2018 by the authors. Licensee MDPI, Basel, Switzerland. This article is an open access article distributed under the terms and conditions of the Creative Commons Attribution (CC BY) license (http:/ / creativecommons.org/licenses/by/4.0/). 